\title{
CLIO POLÍTICA E BIOGRAFIA: \\ RELEVÂNCIA DA BIOGRAFIA, E SEUS USOS, PARA A HISTÓRIA POLÍTICA
}

\author{
CLIO POLICY AND BIOGRAPHY: \\ RELEVANCE OF BIOGRAPHY, AND ITS USES, TO HISTORY \\ POLITICS
}

Jorge Amorim*

\begin{abstract}
RESUMO
Desde a década de 1970 a biografia vem dividindo o patamar de mercado com a historiografia, podendo se adequar como um ramo desta última. Diferente do seu uso panegírico, como ocorreu na antiguidade, o estudo biográfico tende a ser complementado pela memória e pela oralidade, ainda mais quando são investigados quadros políticos. As narrativas tradicionais biográficas merecem o diálogo com a bistória, destacando aquelas de temáticas politicas. Este artigo contribui para a elaboração de uma ótica metodológica importante aos estudos biográficos ao propor uma a maior bumanização da pessoa biografada e menos a sua mitificação.
\end{abstract}

PALAVRAS-CHAVE: Biografia. História. Politica. Metodologia.

\begin{abstract}
Since the 1970s, biography has been sharing market level with historiography, being able to adapt as a branch of the latter. Unlike its panegyric usage, as occurred in antiquity, the biographical study tends to be complemented by memory and orality, even more so when political frameworks are investigated. Traditional biographical narratives deserve a dialogue with history, especially those of political themes. This article contributes to the elaboration of an important methodological perspective to biographical studies by proposing a greater humanization of the biographed person and less of their mythification.
\end{abstract}

KEYWORDS: Biography. Story. Policy. Methodology.

\footnotetext{
* Mestre em História Contemporânea pela Universidade de Lisboa, Portugal. Doutorando em História pela Universidade Federal da Bahia (UFBA). E-mail: amorimdoporto@hotmail.com
} 
O mito é o nada que é tudo.

(Fernando Pessoa, em Mensagem)

\section{DIÁLOGO INICIAL: HISTÓRIA E BIOGRAFIA}

O interesse em saber mais sobre uma personalidade e sobre sua vida esteve em voga para mentes curiosas e divididas em aprender/saber detalhes desconhecidos acerca dela. A aura de alguém intocável, de caráter tido como ilibado, tornou-se a versão oficial que, mesmo para a história biográfica tradicional, não supria a necessidade da reversão não oficial, que não era contada.

Era preferível aproximar figuras de alto realce social a uma espécie de panteão monocromático, herança da época em que loas e divinizações eram legadas aos seres habitantes do alto da pirâmide, principalmente pela pena de quem estava próximo. Era o "direito divino", atribuído a reis e generais por seus canonizadores, os quais ocupavam funções conselheiristas dos seus amos. Isto ocorria para inocular a "síndrome de Clio", que visava eternizar o escolhido ou a escolhida. A ação implicava na responsabilizar de direcionar os olhares para "horizontes de expectativa futura" (KOSELLECK, 2011, p. 11). Ou seja, o registro da história biográfica da personalidade era feito com vista à sua eternização, destacando suas melhores ações, "dádivas divinas".

Mesmo Suetônio (69 (?)-122 (?)), que no seu A vida dos dože Césares (2006) descreve os ancestrais, as ações belicosas, doenças, relacionamentos íntimos e a morte dos imperadores romanos pós-general Júlio César, propaga a ideia eternizante de que estes se apresentam na "majestade dos deuses", que conduzem os imperadores "debaixo de sua autoridade" (SUETÔNIO, 2006, p. 16).

Epopeias, cantos, histórias e o mármore formavam a sequência perfeita para a biografia demarcada em um momento temporal para se fazer presente no imaginário: a descrição de cada traço físico e de cada ato do biografado, desde o seu nascimento, visava conduzir o leitor a incorporar, na sua imaginação, essas descrições gerais, porém sempre as individualizando na figura central.

Era como se a pretensão fosse submeter tudo e todos ao ser enfatizado. E se fossem expostos os seus defeitos ou uma hecatombe por ele desencadeada? Não haveria problema, uma vez que a linearidade da vida revelaria o herói acima do ser humano. Ali estava a grafia do narrador, influenciado pela mentalidade em vigor, que hoje acaba por ser um baú de pérolas.

Tudo se transforma, incluindo a produção de obras voltadas à história da vida individual. Do maniqueísmo das primeiras produções, parcialmente preocupadas em realçar ações boas, aos estudos biográficos realizados desde a década de 1970 se difundiram outros olhares que dialogam com a história e promovem o deslocamento dos reducionismos para a qualidade da "subjetividade e do vivido", categorias pouco observadas. As desmitificações foram sendo pautadas.

A bela face de Dorian Gray, protagonista da clássica obra do irlandês Oscar Wilde (1854-1900) O retrato de Dorian Gray, mostrada ao público leitor britânico da época vitoriana, estava distante da "real" imagem, fétida e carcomida, no quadro. A história pretende não chegar a este ponto de tirar o véu da beleza que oculta a feiura. Caso assim o faça, forjará outra mitificação, elaborada a partir de uma 
tendência única. Ao tematizar a biografia de um famoso nas redes sociais, com um youtuber ou algo desta natureza, um milionário ou milionária, a história versará sobre os diversos matizes da pessoa, podendo esta ser alguém anônimo, com o reforço de vieses historiográficos importantes, a exemplo da memória e da oralidade.

Adentrar pela grafia da vida, seja ela de uma rainha ou de um arrendeiro ${ }^{1}$, é a saída do conhecido para o que, normalmente, passa ao largo. Instagram, Facebook, WhatsApp, Twiiter, Telegram e outros aplicativos sociais e plataformas digitais escancaram a vida das pessoas quase dissecadamente, fazendose, às vezes, em certos momentos, de arena, espelho, divã, tribuna ou altar. As mídias sociais escancaram para likes e curtidas o registro presente ou passado da vida individual. Expõem parte dela, até porque a outra extensão do iceberg individual é conhecida por poucos. Assim também acontece quando fontes desenterram informações sobre a vida de alguém biografado.

Antes de elaborarmos a interrelação metodológica que ocorre entre biografia, memória, oralidade e imagem, nosso debate temático, pretendemos abordar como óticas científicas estudam o vínculo biografia e história

\section{A BIOGRAFIA VISTA POR CLIO E ALGUMAS DE SUAS IRMÃS}

Quando escreveu a biografia de Alexandre Magno (356 a.C.-323 a.C.), o historiador Richard Stoneman disse a que veio ao dizer já no Prefácio, quando afirmou a modéstia do seu material diante dos "aspectos mais notáveis" (STONEMAN, 2008, p. 7) da vida do imperador macedônico. Propoôs-se, pois, a realizar a tarefa caminhando pela linearidade com base em fontes baseadas noutras fontes, trazendo ao debate "pontos de vista morais bastante diferentes" (STONEMAN, 2008, p. 25).

Stoneman, na contemporaneidade, segue a proposta de desmistificação do vangloriado Alexandre, o Grande, iniciada na antiguidade pelo historiador romano Suetônio, no clássico A vida dos Doze Césares. Se, nas épocas feudal e moderna, a sacralização biográfica imperou na maior parte dos trabalhos, os mais próximos de nós, a partir dos anos 70 e 80 do século XX o empreendimento dissecador da divindade individual está em declive. Quais razões?

Os mesmos instrumentos usados como referenciais, a exemplo de arquivos escritos e orais que contribuíram para organizar a "representação do personagem" (LEVILLAIN, 2003, p. 155), passaram por uma mudança de $360^{\circ}$ e, ao invés de reproduzirem o esquema "nascimento-crescimentodesenvolvimento-morte" do protagonista, incorporaram a hermenêutica daqueles referenciais, além de incorporar novos, como imagens e imaginário.

Não sendo um luxo isolado, a biografia deve ser delineada incluindo contexto, lugar e comportamentos, o que para o historiador biográfico é condição para a transição do particular para o geral e do geral para o particular, num movimento de retroalimentação recíproca.

\footnotetext{
${ }^{1} \mathrm{O}$ termo, muito usado em localidades do Recôncavo baiano e em outras partes da Bahia, refere-se à pessoa que trabalha por renda numa fazenda ou plantação agrícola.
} 
A biografia vista pela história precisa ser clássica, não necessitando tão-somente de retorno às origens do biografado. Deve incluir o resultado do contato com informações escritas e não-escritas que podem dialogar com as "verdades" conhecidas e desconhecidas.

A linearidade conta como relevante suporte para se ter um arrimo. Isso não quer dizer, precisamente, que o suporte deve ser buscado no pós-trazido à luz ou desde os cueiros. Depende do historiador e de sua pena. A mitificação é um enclave que, a todo instante, estará presente para ser destravado, exigindo evitar o maniqueísmo que sombreia a análise científica do historiador biográfico. Independente da exaltação que hegemoniza nos estudos de uma pessoa, a mitificação não pode ser um obstáculo a emperrar o "julgamento crítico do historiador” (LEVILLAIN, 2003, p. 142).

Por ter ajudado milhões, criado programas governamentais de caráter social, desafiado o sujeito oculto chamado sistema, por ser um "modelo" de cidadão, por ter composto belas canções, pintado ou esculpido obras imortalizadas ou, ainda, por ter escrito textos profundos, uma pessoa pode ser denominada "mito". O verso e o reverso da trajetória de vida dessa pessoa ou personalidade, ou parte dela, não deverão ser estudados em conjunto, guardando as devidas proporções?

O interessante é a busca da singularidade humana. Se, para decifrar a complexidade adulta, é necessário a volta à aurora, que se recorra a esta luz! Essa é a base, mas não é a única. Características comportamentais observadas em um político, por exemplo, podem estar embrionadas na adolescência, fase em que a parceria psicologia-psicanálise-história é situada, conforme Philippe Levillain (2003, p. 169).

Psique, genes, o local e o global se misturam na nossa formação geral, motivada a se desenvolver na sociedade, e em outras, que nós contatamos. O acréscimo de conceitos ao longo de vivências e convivências contribui para a formação do imaginário comportamental, emaranhado de pontos expostos e recônditos do indivíduo.

Pode-se entender determinado meio social a partir do ser individual? Pode-se auferir informações várias do ser que traz a carga do meio. O indivíduo é fruto de um âmbito, paráfrase à máxima rousseauniana, assim como o meio é caule de cada pessoa. O resultado não vive sem sua base. Fatos e forças sociais se irmanam ao indivíduo que, só, inexiste (PRIORE, 2018, p. 79).

À história, ou melhor, ao analista-estudioso da história, a biografia segue padrões disciplinares exigidos pela ciência. Por exemplo, deve-se evitar o link com questões anacrônicas, isto desde a semântica até às formas de pensar específicas de um contexto. Agora, a depender da pessoa, há comportamentos e termos gramaticais que ficam e/ou são aprendidos nas novas épocas.

Compreender o passado e explicá-lo partindo do indivíduo é utilizá-lo como um avatar, colocado como olhos, ouvidos e mente que saem do presente para migrar ao passado. Seria como o vocativo do historiador dizendo ao passado do/a biografado/a: "Formosos olhos contemplam vossos feitos", como se lê em Ivanhoé, clássico de sir Walter Scott. 
Há um sujeito específico para ser biografado, para ser contemplado por olhos abnegados? Nem todas as pessoas deixaram "feitos" diferenciais nos quais marcaram sua passagem no mundo, não importando a esfera socioeconômica.

O alvo que se quer obter diz respeito às dimensões do passado (SCHMIDT, 2012, p. 195), a priori saindo da figura biografada. Esta não deve ser fechada em torno de si para mostrar a síndrome do umbigo, sendo, na verdade, o mote central para entender o seu redor. Isto é relevante de tal forma que possa trazer os traços de uma época que, muitas vezes, sumiram com o tempo.

Documentos escritos, memoriais, orais e imagéticos, incluindo o biografado e seu contexto, proporcionam à história a delimitação do lugar e da época. Para completar, antropologia, geografia, sociologia e ciência política são as “irmãs de Clio" cabíveis para o diálogo, que impactam na ampliação de matizes biográficas.

Se se diz que em um podem ser encontrados muitos outros, a história biográfica caminha com a interdisciplinaridade. Investigar alguém somente pela linearidade prosopográfica seria a reprodução concisa do curso da vida, o que solicita a ajuda das ciências humanas irmãs. Prosopografia somente em informações breves que o estudo solicita.

O entendimento amparado pelo olhar antropológico do conviver e viver do biografado ou da biografada proporciona detectar os comportamentos obtidos no lugar e na região de nascimento e convivência. O interessante ao historiador biográfico é falar do ser estudado in loco, no âmbito de vivência e convivência.

Além disso, a cartografia física presente na formação de uma pessoa mostra o quanto acidentes geográficos influem na formação do indivíduo, adaptado ao meio pela sobrevivência de si e dos seus. Se, de acordo à máxima iluminista, o ser humano é fruto do meio, a geografia local/regional tem peso relevante ao menos quanto à sua adaptação.

Relacionamentos sociais, esfera socioeconômica de origem, instituições, partidos políticos, laços políticos e formas de poder são teias edificadas peculiarmente no local, imbuídas da função de caracterizar as ações individuais. Sociologia e ciência política se integram, pois, à história biográfica como arrimos da análise interdisciplinar.

\section{A BIOGRAFIA E SEUS USOS METODOLÓGICOS...}

Extrair informações para aspirar uma metodologia que construa biografias serve para a desmistificação e desmitificação, tendo como corolário a real humanização nua e crua da idiossincrasia biografada. Oralidade, memória e documentos imagéticos retificam o quantum podem garantir informações historiográficas.

\section{... COM A HISTÓRIA ORAL}

Apesar de algumas desconfianças ainda presentes por uma parte da historiografia, a história oral é, por excelência, um gênero multivocal (PORTELLI, 2017, p. 20) que valoriza a diversidade verbal. 
O positivo ao oral condiz à humanização individual de quem fala ao receptor, uma fala que guarda a experiência de quem viveu e conviveu com a pessoa biografada ou ouviu dizer, o que não minoriza esta última ação como irrelevante.

O baú amplamente profundo da oralidade consegue ser o filtro dominado por racionalidades e emoções, a modelo da política brasileira que, vez ou outra, tem entre seus quadros alguns que adoram agir como Jesus Cristo na passagem da ressurreição que ele fez de Lázaro: trazer à vida alguém - ou algo - que parecia ter desencarnado. Daí nossas "pérolas” populista-coronelistas, motivadoras de paixões forjadoras de "nós e eles" e "mitos".

$\mathrm{O}$ ato prático da oralidade é mais do que o tète-à-tète entre emissor e receptor. Ambos têm proximidade ou não importa o desembaraço da pesquisa, há um diálogo sem pressão e imposição, levando a reações leves que resultam em informações de uma conversação motorizada pelas reações entre as partes (PORTELLI, 2017, p. 19-20).

O ato de biografar alguém sem relatos dos seus contemporâneos enfraquece outras fontes. A descrição física, os caracteres pessoais internos e comportamentais multivocalizam o que ficou anexado à memória do indivíduo. Os fatos centrais, por serem notórios, não podem ser os únicos, valendo a pena obter pormenores das bocas dos entrevistados. Esses pormenores promovem a emersão de realidades da pessoa biografada que são inobservadas em registros escritos e imagéticos, além de estarem discretos nas versões mais conhecidas. As entrevistas de "prós" e "contras" para falar de alguém corresponde a retirar a espada de Dâmocles da parcialidade panfletária, algo que seduz a leitura biográfica.

Por qual razão?

Pela tendência ao panegírico, à defesa de interpretações que andam doidas - sempre! - para construir altares a "santos humanizados", canonizados às vezes por beletristas, às vezes pelas vozes populares. O dito “mito”, conforme o poeta lisboeta Fernando Pessoa (1888-1935), "é o nada que é tudo", mas, para criadores e seguidores do mito, este “é a parte que é tudo".

A pretensão de se compreender este bojo merece a contribuição da oralidade, aliada da memória, e que recebe o arrimo de registros escritos. Em conjunto, o oral e o escrito possuem limitações as quais atiçam interesses, ainda mais a oralidade (JOUTARD, 2006, p. 34). A segurança desta é auferida pelas diferentes falas, rememorações e documentos a partir do biografado ou da biografada.

A largada para coleta de dados orais, é claro, parte da família, onde as informações diretas são recolhidas, iniciando pelas lembranças saídas dos lábios parentais. Ela se desdobra a outros familiares que interessem ao biógrafo historiador, sendo contrapesadas por outros depoimentos de fora da família que contribuem com observações variadas.

Aliados às verbalizações estão as análises dos seus teores, juntamente à leitura importante dos gestos e expressões (JOUTARD, 2006, p. 35), isto é, das movimentações que olhos, boca, rosto, mãos, tronco e pernas fazem ao estarem na gangorra entre a leve tensão e o relaxamento dos depoimentos. A fala pura e seca, sem aqueles detalhes corporais, os quais requerem o olhar arguto do historiador biográfico, tornam o registro com pouca vitalidade. 
As lembranças parciais - falar bem e/ou mal - e imparciais - se isto for possível - devem ser farejadas pelo pesquisador no exercício cartesiano da biografia. Iniciar pelo geral, ficar nele e rechaçar o específico podem significar uma tentativa de tendenciamento, o que pode ser o objetivo da escrita de quem biografa. Quanto mais visões/depoimentos diferentes, melhor para o leitor.

\section{... COM A MEMÓRIA}

Unida à oralidade como irmã xifópaga, a memória é a faculdade do ser humano capaz de acompanhá-lo por toda a vida e de, naturalmente, priorizar o que lhe interessa. O poder de descartar o que é pouco relevante para fazer a triagem do que é escolhido torna o campo mnemônico algo fértil para o trabalho histórico que se digne biográfico.

A conversa entre o pesquisador e o entrevistado, sendo realizada em local e momento - horário! - adequados, tem tudo para presentear aquele com "pérolas". Dúvidas podem ocorrer - daí o uso dialógico de registros escritos e imagéticos -, caracterizando o que Nietzsche (1844-1900) chamou de “causalidade verdadeira” (NIETZSCHE, 2018, p. 41). Isso pode se tornar um bábito (NIETZSCHE, 2018, p. 41), o que não quer dizer que as hesitações do historiador biográfico devam ser barradas.

Saber o além-conhecido sobre o estudo da vida de alguém é ter a memória como trampolim para obter pulos altos, acima do notório. Ao buscar puxar das lembranças da pessoa entrevistada o desconhecido, o historiador biográfico primeiramente ri para dentro, depois passa por reações de liberação da endorfina que o fazem pensar como a pessoa mais feliz do mundo naquele instante.

O embate-cruzamento de dados memoriais diferentes em torno de um caráter ou comportamento da pessoa biografada, normalmente o mais notório, amplia as multiplicidades de respostas que quebram clichês. Se o pesquisador souber conduzir a confabulação sem leviandades, a resultados obtidos vão beirar a maioria dos objetivos.

$\mathrm{O}$ assassinato de uma liderança política, por exemplo, mormente quando ocorrido em um lugarejo onde paredes-e-meia são adstritos, marca a memória coletiva de tal forma nos instantes após o crime que o tempo - sempre ele! - ficará com a responsabilidade de peculiarizar a recordação das passagens d dia fatídico que abalou o local. Entra aqui em vigor recordar os momentos, as reações das pessoas e a da pessoa entrevistada e as características de como estava o tempo.

As estratégias para obter respostas ao que se pretende vai depender do pesquisador: não é aconselhável ir muito afoito para galgar o que quer, pois, ao mesmo tempo que pode conduzir o/a entrevistador/a à "vontade de recordar”, conforme afirma João Medina (2004, p. 35), pode levá-lo a "uma vontade de esquecer" (MEDINA, 2004, p. 35).

Eis o cuidado essencial à biografia histórica: ter calma e resiliência ante às frustrações que venham a surgir. Bola pra frente! O imaginário individual é um universo inóspito, desconhecido, rico, açambarcador, móvel, imutável e facilitador. Saber sobre alguém depende de ter a pergunta certa para que as respostas estejam além das expectativas. 
A “ressurreição" historiográfica de um/a biografado/a diz respeito, em geral, a compreender o contexto, com base no indivíduo. Sem querer menosprezar os anônimos, ser invulgar e ter notoriedade é fundamental para tornar-se sujeito de estudo. O historiador alcança respostas num pequeno diálogo de poucos minutos ou de várias horas. As profundezas cerebrais, cheias de eventos marcantes, se mantêm intactas, a depender de cada pessoa, não importando a idade. Lógico que problemas degenerativos como o mal de Alzheimer e alguns vulgares, provocados pela descartabilidade natural do cérebro, podem ser grandes obstáculos ao pesquisador.

A quem este deve recorrer?

Pergunta complicada, embora não seja difícil de responder quando se trata de fazer uma biografia. De pessoas próximas, amigas, inimigas, adversárias e distantes, os tijolos em forma de respostas mnemônicas contribuem para a "construção" da pessoa estudada. Deter boas informações adiantam bastante, ainda mais quando se pode obtê-las por redes sociais. Por exemplo, contatos do Whats $A p p$, Instagram, Facebook e/ou Telegram, que garantem notícias alheias e likes, assim como resgastes das memórias dos "seguidores" que, à distância, economizam deslocamentos e tempo. Pode-se pesquisar por áudios, registrando dia, horário e qual rede social utilizada, e deixar a cargo do/a entrevistado/a reenviar, com sua voz, as investigações almejadas.

As memórias, conforme dizem Cardoso e Cardoso (2017, p. 15), são “livros em aberto". Nelas estão semeadas emoções as mais diversas, as quais, mescladas à oralidade, se fortalecem. Esta força, todavia, torna-se mais nutrida ao ser vitaminada pelo uso de imagens.

\section{... COM AS IMAGENS}

As imagens podem se plasmar com a história (ROSENSTONE, 1998), serem indispensáveis ou enganosas (SORLIN, 1994), como já discutido por estudiosos. Elas carregam o peso de visibilizar e mostrar o que a oralidade e a memória só conseguem demonstrar por vozes e falas.

Expor a silhueta em diferentes posições garante maior crédito para a relevante biografia. Podese haver a tentativa de se biografar tão somente por parágrafos, letras e pontos de acentuação. É até possível. Mas melhor ficará essa investigação com o apoio de registros imagéticos obtidos de álbuns de família, jornais, molduras, estátuas e bustos. Como estes registros - imagens paradas -, as trajetórias completas ou parciais retratadas em imagens em movimento ganharam telas de cinemas, documentários e séries em streaming, atraindo mais expectadores às salas, aos televisores e telas de computadores, notebooks e smartphones. Em geral, last but not least, até mesmo os games de aplicativos se transformaram nos mensageiros das novas linguagens pictóricas móveis.

Congeladas ou móveis, as imagens sobre um/a biografado/a promovem informações dos contextos vividos, das pessoas convividas, dos comportamentos, da intencionalidade, do formato e da ideia subexposta, muitas vezes inclinadas à formatação/intenção iconólatra. A mobilidade imagética é forjada para a captação rápida e fácil.

Agora vamos à fotografia. 
Estas nuances textuais, sujeitas à interpretação do historiador (CARDOSO; MAUAD, 1997), cabem como uma luva ao se estudar uma biografia, fortalecidas com os registros escritos, orais e memoriais. O que está sendo dito pelo registro fotográfico de uma liderança política abraçada com populares defronte a um templo religioso, em uma festa de largo ou praça pública? Afã momentâneo, objetivo mera e politicamente intencional ou involuntário... ou ambos?

As respostas a estas indagações têm um ganho com a abordagem dos gestos faciais registrados no clichê, o que não deve ser limitado ao que se vê. Tendenciar somente pela imagem é discriminar outras leituras acompanhantes, essencialmente necessárias a alicerçar o que salta aos olhos. Importa defenestrar a "incólume" inserção de fotos e apostar em legendas explicativas, se possível com data, informações sobre quem registrou a imagem, onde e a quem pertence.

A informação sobre o proprietário do documento pode contribuir em demasia, se encontrada na imagem. Sua ajuda possa exceder o empréstimo do documento pictórico. Ele pode participar com a rememoração do momento estigmatizado no clichê e, com suas palavras, pode-se obter informações das lembranças da situação, das emoções e das impressões do entrevistado. Essas informações propõem um olhar investigativo do historiador biográfico, importante para se erigir um debate que envolva outros registros, tudo objetivando se avizinhar a verdades.

A relação esquemática escrita-memória/oralidade-fotografia pode obedecer ou não estar submetida a uma ordem no trabalho biográfico, creditando-se o mérito ao que pretende o/a pesquisador/a. Pode-se expor o clichê, debatê-lo em si e, depois, confrontá-lo com os documentos. Nada mais interessante do que entrevistar alguém sobre uma trajetória mostrando um evento ao qual o entrevistado estava junto com o biografado/a. Recordações e pontos de vista estimulados pela fotografia virão à tona, os quais terão como régua material os escritos que, porventura, façam parte do conjunto documental ou mesmo outros olhares acerca do momento registrado. A atenção à triagem de eventos fotografados e dos entrevistados contidos neles e, consequentemente, endossados por escritos formam a análise bem nutrida.

\section{CONCLUSÃO}

A biografia que lida com a pena desmitificadora está na contramão do personalismo sensual, caracterizado pelo messianismo, insistente no mundo atual. Em tempos de "ismos" que tentam conceituar e dar organicidade mitificante a lideranças, a lente analítica deve ser o fio de Ariadne.

A utilidade de ferramentas documentais que buscam edificar um/a biografado/a depende da metodologia escolhida pelo/a pesquisador/a entre aquelas que possam ser capitaneadas pelas que foram discutidas aqui. Os documentos são pérolas passíveis de ser obtidas, muitas vezes empoeiradas, em arquivos familiares, particulares e públicas. Ao historiador/a biográfico/a cabe estar antenado. 


\section{REFERÊNCIAS}

CARDOSO, C. C.; CARDOSO, L. C. Introdução. In: CARDOSO, C. C.; CARDOSO, L. C. (org.). Ditaduras, memória, violência e silenciamento. Salvador: Edufba, 2017. p.13-27.

CARDOSO, C. F.; MAUAD, A. M. História e imagem: os exemplos da fotografia e do cinema. In: CARDOSO, C. F.; VAINFAS, R. (org.). Domínios da História: ensaios de teoria e metodologia. Rio de Janeiro; Campus, 1997. p. 401-417.

JOUTARD, P. História oral: balanço da metodologia e da produção nos últimos 25 anos. In: AMADO, J.; FERREIRA, M. de M. (org.). Usos \& abusos da história oral. Rio de Janeiro; Ed. da FGV, 2006. p. 43-62.

KOSELLECK, R. Futuro passado: contribuição à semântica dos tempos históricos. Rio de Janeiro: Contraponto; Ed. da PUC-Rio, 2011.

LEVILLAIN, P. Os protagonistas: da biografia. In: RÉMOND, R. (org.). Por uma história politica. Rio de Janeiro: Ed. da FGV, 2003. p. 141-184.

MEDINA, J. A toponímia: local de memória. In: MATOS, S. C.; RASGA, R. (coord.). Primeiras jornadas de história local e regional. Lisboa: Faculdade de Letras da Universidade de Lisboa; Colibri, 2004. p. 35-44.

NIETZSCHE, F. W. Crepúsculo dos ídolos: como filosofar a marteladas. São Paulo: Lafonte, 2018. p. $37-44$.

PORTELLI, A. Ensaios de história oral. São Paulo: Letra e Voz, 2017.

PRIORE, M. del. Biografia, biografados: uma janela para a história. In: AVELAR, A. de S.; SCHMIDT, B. B. (org.). O que pode a biografia. São Paulo: Letra e Voz, 2018. p. 73-89.

ROSENSTONE, R. História em imagens, história em palavras: reflexões sobre as possibilidades de plasmar a história em imagens. O Olho da História, v. 1, n. 5, p. 105-116., set. 1998.

SCHMIDT, B. B. História e biografia. In: CARDOSO, C. F.; VAINFAS, R. Novos domínios da História. Rio de Janeiro: Elsevier, 2012. p. 187-205.

SORLIN, P. Indispensáveis e enganosas, as imagens, testemunhas da História. Novos Estudos Cebrap, v. 7 , n. 13, p. 81-95, 1994.

STONEMAN, R. Alexandre, o Grande. Lisboa: Edições 70, 2008.

SUETÔNIO. A Vida dos Doze Césares. São Paulo: Martin Claret, 2006.

Data de submissão: 23/09/2021

Data de aprovação: 15/12/2021 